\title{
1.3.2. Kompetencje zawodowe - jakie wyzwania?
}

DOI: 10.47050/65591838.54-61

Iwona Chrzanowska, Grzegorz Szumski

W wielu krajach inicjujących zmiany w edukacji w kierunku inkluzji (włączania) jednym z istotnych zagadnień jest próba zdefiniowania, jakie kompetencje powinien posiadać nauczyciel, by mógł skutecznie pracować z dziećmi w przedszkolu i szkole ogólnodostępnej, w zróżnicowanych grupach. Rozważania dotyczące wyzwań warto podzielić na dwie części.

Pierwsza skoncentruje się na realiach i perspektywach kształcenia przyszłych nauczycieli, a także na doskonaleniu zawodowym osób już pracujących. Druga dotyczy wymagań wynikających z idei edukacji włączającej z punktu widzenia kompetencji nauczycielskich.

Wyzwaniem kompetencyjnym nauczycieli są realia kształcenia i doskonalenia zawodowego. Dane Europejskiej Agencji Rozwoju Edukacji Uczniów ze Specjalnymi Potrzebami Edukacyjnymi ${ }^{3}$ pokazują, że jednym z kluczowych wymogów wobec kandydatów na nauczycieli na całym świecie są odpowiednio wysokie wyniki końcowe na świadectwie umożliwiającym ubieganie się o kształcenie na poziomie wyższym (Europejska Agencja 2011, s. 21). Tymczasem polskie diagnozy (NIK 2017) wskazują na wyraźnie zarysowujące się zjawisko negatywnej selekcji w rekrutacji na studia, kierunki i specjalności nauczycielskie. Okazuje się, że 9,3\% osób przyjętych w roku akademickim 2014/2015 uzyskało na egzaminie maturalnym najniższe wyniki (średnio od 30 do 49 punktów, czyli minimalny poziom umożliwiający uzyskanie 
pozytywnego wyniku egzaminu) (NIK 2017, s. 7, 25). Jednocześnie, jak wynika z analiz, wzrastają wskaźniki dotyczące osób, które w terminie nie obroniły prac dyplomowych i magisterskich. W roku akademickim 2012/2013 dotyczyło to odpowiednio: 37\% i 47\% studentów, w 2014/2015 - 47\% i 56\% (tamże, s. 24). Na bardzo wysokim poziomie znajdują się również wskaźniki "odsiewu" w trakcie studiów. Średnio ponad jedna trzecia $(36,4 \%)$ osób na kierunkach nauczycielskich zostaje skreślona z listy studentów (tamże, s. 29). Dane te znajdują potwierdzenie w problemach sygnalizowanych przez środowisko nauczycieli akademickich, ale również przez samych studentów, którzy, jak wynika z badań Najwyższej Izby Kontroli, mówią o konieczności podwyższenia wymagań rekrutacyjnych (poprzez wprowadzenie egzaminów wstępnych, rozmów kwalifikacyjnych, testów psychologicznych, badań przydatności zawodowej). Studenci podkreślają, że wśród ich kolegów na kierunkach nauczycielskich są tacy, którzy nigdy nie powinni wykonywać tego zawodu - ze względu na brak predyspozycji, wiedzy i umiejętności.

Studenci apelują o poprawienie jakości kształcenia nauczycieli oraz o podwyższenie wymagań, by nastąpił naturalny "odsiew" i dyplom otrzymywali jedynie ci, którzy są zdeterminowani, pracowici, posiadają wiedzę i odpowiednie umiejętności. Jednocześnie dostrzegają oni również poważny problem związany z prestiżem zawodu w Polsce (NIK 2017, s. 26). Tymczasem analizy wyników badań międzynarodowych pokazują jednoznacznie, że najlepsze systemy edukacyjne na świecie opierają się nie tylko na jakości kształcenia i dbałości o pozyskanie najlepszych kandydatów do zawodu, ale także na zapewnieniu im doskonałych warunków pracy (Europejska Agencja 2011, s. 23). Przykładem jest Finlandia - kraj kształcący uczniów niezmiennie plasujących się w czołówce wyników w światowych badaniach kompetencji. Obowiązują tam wyśrubowane wymagania wstępne na studia nauczycielskie, a sam proces rekrutacyjny jest wieloetapowy. W rezultacie tylko najlepsi kandydaci mogą podjąć edukację, a chętnych wśród młodych ludzi nie brakuje. Status profesji jest bardzo wysoki, porównywalny z zawodem lekarza i prawnika (Fazlagić 2014). 
Inne wyzwanie związane z kształceniem nauczycieli zostało zdefiniowane przez UNESCO. Jest nim konieczna zmiana programów studiów dotycząca wprowadzenia do nich problematyki edukacji włączającej (UNESCO 2008). Z uwagi na różnice w systemach kształcenia zawodowego nauczycieli w różnych krajach ich porównanie jest bardzo trudne. Analiza raportów z 29 państw wskazuje, że w mniej niż 10\% z nich oferowana jest specjalizacja z zakresu specyficznych potrzeb edukacyjnych na pierwszym etapie kształcenia wyższego (studia licencjackie). W większości krajów w ramach niektórych przedmiotów wprowadzane są zagadnienia związane z zaspokajaniem indywidualnych wymagań uczniów. W niektórych ograniczają się one do problematyki specjalnych potrzeb i niepełnosprawności, w innych dotyczą potrzeb w odniesieniu do wszystkich uczniów. Treści te są realizowane w postaci jednego modułu lub dwóch (przedmiotów w planie studiów), a w niektórych krajach w ramach dłuższych kursów, nierzadko obligatoryjnych. W Szwajcarii zagadnienia dotyczące szeroko rozumianej edukacji włączającej (specjalne potrzeby edukacyjne, praca w grupie zróżnicowanej itp.) stanowią $5 \%$ programu studiów dla nauczycieli szkół podstawowych i ponadpodstawowych (Europejska Agencja 2011, s. 28). Podobnie jak w Polsce, częściej treści dotyczące problematyki edukacji włączającej pojawiają się w programach edukacji wczesnoszkolnej niż na kierunkach nauczycielskich związanych z kształceniem przedmiotowym.

Rzadko na świecie (w Europie) kształcenie z zakresu edukacji włączającej odbywa się w osobnych modułach. W Niemczech dzieje się tak na połowie uczelni (w zakresie wczesnej edukacji), w Danii tematyka inkluzji omawiana jest nadal $w$ ramach programu $z$ pedagogiki specjalnej, z kolei w Hiszpanii zajęcia z zakresu edukacji włączającej sprowadzają się w zasadzie do specjalnych potrzeb edukacyjnych (Europejska Agencja 2011, s. 25-26).

W Polsce, jak wskazują analizy przeprowadzone przez Beatę Jachimczak, kształcenie w zakresie edukacji włączającej stanowi połączenie wspomnianych wcześniej rozwiązań. W ofercie $22 \%$ uczelni publicznych (4 z 18 uniwersytetów) znajduje się specjalizacja dotycząca edukacji włączającej, w większości wypadków koncentrująca się na problematyce specyficznych potrzeb edukacyjnych i niepełnosprawności uczniów. Skierowana jest do nauczycieli wczesnej edukacji (przedszkolnej, wczesnoszkolnej) (Jachimczak 2018, s. 41). Wręcz dramatycznie źle przedstawia się ta sytuacja w odniesieniu do kształcenia przedmio- 
towego (od klasy IV szkoły podstawowej i wyżej). W programach studiów nauczycielskich nie tylko nie ma treści związanych z problematyką włączania, ale również pedagogiki specjalnej czy zajęć dotyczących specjalnych potrzeb edukacyjnych. Absolwenci kończący kształcenie nauczycielskie nie mają zatem żadnej wiedzy na temat ucznia z niepełnosprawnością i ze specjalnymi potrzebami edukacyjnymi, pracy w grupie zróżnicowanej, projektowania działań wspierających, dostosowywania wymagań, organizacji kształcenia i treści.

Nauczyciele (i nie tylko oni) mogą zwiększyć kompetencje w tym zakresie $w$ ramach doskonalenia zawodowego $w$ trakcie studiów podyplomowych kwalifikacyjnych lub doskonalących, a także kursów i szkoleń. Kwestia ta omawiana była w poprzednim podrozdziale, warto jednak przypomnieć wynikającą z badań zależność, że im wyższy etap edukacyjny szkoły ogólnodostępnej, tym mniejsza liczba nauczycieli doskonali się zawodowo, w tym w zakresie poruszanej tu problematyki. Nie wynika to z ich ignorancji czy niechęci wobec zdobywania nowych umiejętności, a raczej z mniejszej liczby uczniów ze specjalnymi potrzebami edukacyjnymi czy z niepełnosprawnością, z którą mają szansę się spotkać. Wynika to z prostego faktu - na etapie przedszkolnym i wczesnoszkolnym uczniowie ze specjalnymi potrzebami uczestniczą w edukacji włączającej w większej liczbie, jednak zauważalnie ubywa ich wraz z przechodzeniem na kolejne poziomy. Z danych Systemu Informacji Oświatowej (SIO 2017) wynika, że o ile w szkołach ogólnodostępnych na poziomie podstawowym w roku szkolnym 2017/2018 znajdowało się ok. 63,3 tys. uczniów ze SPE, o tyle na etapie edukacji ponadpodstawowej już jedynie 28,6 tys., co oznacza, że ponad połowa z nich (55\%) nie kontynuowała nauki w szkole ogólnodostępnej po ukończeniu edukacji podstawowej. W szkołach specjalnych wielkości te wynoszą odpowiednio: 30,4 tys. i 24 tys.

W opinii osób z niepełnosprawnością barierami wpływającymi na zmianę ścieżki kształcenia są: brak akceptacji ze strony rodziców uczniów sprawnych oraz samych uczniów, niedobór specjalistów w szkołach ogólnodostępnych, zbyt liczne klasy, nieprzygotowanie uczniów przez szkołę do wejścia na rynek pracy, brak rzetelnej diagnozy, ale również nieakceptowanie niepełnosprawności dziecka w jego rodzinie, nadopiekuńczość osób bliskich (Sochańska-Kawiecka, Makowska-Belta, Milczarek, Morysińska, Zielińska 2015, s. 38-39). Niektóre z tych barier wprost, a wszystkie pośrednio, będą wyzwaniem dla nauczyciela, 
który wykorzystując swoje kompetencje, będzie musiał minimalizować niekorzystne ich skutki, umożliwiając funkcjonowanie ucznia w ramach edukacji włączającej.

Kolejne wyzwanie dotyczące kompetencji zawodowych nauczycieli w ramach edukacji włączającej to realizacja stażu zawodowego, a raczej adaptacji zawodowej i rozwoju zawodowego nauczycieli stażystów. Analizy NIK ${ }^{5}$ wskazują niepokojące fakty dotyczące polskich doświadczeń w tym zakresie, np. że blisko jedna czwarta opiekunów stażu nie ma doświadczenia lub większych osiągnięć zawodowych (przez cały okres ich pracy). Plany rozwoju zawodowego stażysty nie były ukierunkowane na przyrost konkretnych umiejętności, nie uwzględniały istotnych kompetencji niezbędnych w rozwoju zawodowym - miały przeważnie charakter ogólny, schematyczny, stanowiąc zbiór osobnych, niespójnych działań. Uniemożliwiało to monitorowanie postępów uczestnika stażu i ocenę jego dorobku zawodowego. Ponadto procedura awansu zawodowego nie była powiązana z doskonaleniem zawodowym. Więcej niż jedna czwarta planów rozwoju była identyczna, pozostałe były w znacznym stopniu podobne (NIK 2017, s. 9). Trzeba przy tym zauważyć, że dodatek finansowy za opiekę nad nauczycielem stażystą jest bardzo niski (30-150 zł, a w połowie szkół 30-75 zł) (tamże, s. 8). Procedura awansu nauczycieli w Polsce jest nieprzesiewowa. W latach 2014-2016 jedynie 0,2\% stażystów nie uzyskało wyższego stopnia zawodowego w efekcie przystąpienia do postępowania. Zbliżone były wskaźniki na kolejnych etapach awansu: 0,4\% z nauczyciela kontraktowego na mianowanego, 0,7\% z mianowanego na dyplomowanego (tamże, s. 13).

Dane GUS z lat 2014-2015 wskazują, że największą grupę w kadrze edukacyjnej stanowią osoby ze stopniem nauczyciela dyplomowanego $(54,9 \%)$, następnie są nauczyciele mianowani $(23,1 \%)$, kontraktowi $(15,1 \%)$, stażyści (4\%) i bez stopnia awansu (3\%) (Oświata i wychowanie 2017, s. 118). Ponad połowa nauczycieli mogłaby zatem stanowić naturalne środowisko liderów, w tym dla edukacji włączającej, gdyby zbagatelizować wyniki kontroli NIK i nie przejmować się niepokojącymi wskaźnikami sygnalizującymi nieprawidłowości w całym procesie awansu. terytorialnego z województw: zachodniopomorskiego, pomorskiego, kujawsko-pomorskiego, mazowieckiego, dolnośląskiego. 
Wieloletnie niekorzystne tendencje w zakresie przygotowywania nauczycieli i ich rozwoju zawodowego mogą być bardzo ważną barierą w rozwoju edukacji włączającej na wysokim poziomie. Trzeba mieć świadomość, że efektywne jej wdrażanie jest trudne i wymaga zaangażowanej kadry pedagogicznej o dużych kompetencjach zawodowych.

W dotychczasowych badaniach na temat uwarunkowań efektywności nauczycieli w zakresie edukacji włączającej ustalono, że istnieją trzy grupy czynników o kluczowym charakterze: postawa wobec tej idei i przekonanie na temat istoty niepełnosprawności, poczucie samoskuteczności w kształceniu klas włączających oraz posiadane umiejętności metodyczno-organizacyjnych (Jordan, Schwartz, McGhie-Richmond 2009; Europejska Agencja Rozwoju Edukacji Uczniów ze Specjalnymi Potrzebami 2012). Ponieważ każdy z tych czynników podlega zmianom i daje się, przynajmniej w pewnym zakresie, formować w toku kształcenia, dokształcania i doskonalenia, powinny być one uwzględnione w programach nauczania.

Postawy nauczycieli wobec edukacji włączającej są przedmiotem licznych analiz na całym świecie (Avramidis, Norwich 2002; De Boer, Pijl, Minnaert 2011). Niestety, większość z nich wskazuje, że są one $z$ reguły neutralne lub negatywne. Spośród 26 badań szkół podstawowych objętych systematycznym przeglądem żadne nie wskazywało na to, że nauczyciele mają pozytywne postawy wobec włączania uczniów z niepełnosprawnością (De Boer i in. 2011). Podobne wyniki uzyskiwano w wielu polskich badaniach (por. Parys 2007). Istnieją jednak dowody na to, że nastawienie pedagogów wobec edukacji włączającej można poprawiać przez odpowiednie szkolenia. Przykładem może być zaledwie 28-godzinny kurs dla nauczycieli izraelskich i palestyńskich, który przyczynił się do zmiany ich postaw wobec włączania uczniów z większością rodzajów niepełnosprawności (z wyjątkiem lekkiej niepełnosprawności intelektualnej, zaburzeń zachowania i głębokich trudności w uczeniu się) (Lifshitz, Glaubman, Issawi 2004). Program szkolenia dotyczył koncepcji normalizacji i włączania, prawnych regulacji kształcenia uczniów z niepełnosprawnością w Izraelu i Autonomii Palestyńskiej, rozwoju edukacji włączającej w krajach przodujących w jej upowszechnianiu, dylematów moralnych związanych z wykluczaniem dzieci z niepełnosprawnością, zawierał również elementy metodyczne (Lifshitz i in. 2014). Wyników wskazujących na pozytywną rolę kształtowania postaw nauczycieli wobec edukacji 
włączającej dostarczają także badania z innych krajów (np. Avramidis, Kalyva 2007; Kim, Park, Snell 2005).

Czynnikiem silnie związanym z postawami nauczycieli są ich przekonania na temat istoty niepełnosprawności. Anne Jordan, Eileen Schwartz i Donna McGhie-Richmond (2009) twierdzą, że mogą mieć one charakter „patogeniczny" lub „interwencjonistyczny". W pierwszym wypadku nauczyciele koncentrują się przede wszystkich na ograniczeniach w przyswajaniu wiedzy wynikających z niepełnosprawności, w drugim zaś na optymalnych sposobach nauczania/uczenia się podopiecznych z danym rodzajem niepełnosprawności. Istnieją dowody, że to drugie podejście zwiększa skuteczność nauczania wszystkich uczniów, gdyż identyfikujący się z nim nauczyciele rzadziej doszukują się u nich zaburzeń oraz rzadziej cedują odpowiedzialność za ich kształcenie na specjalistów i rodziców (Jordan i in. 2009). Z badań zespołu Anne Jordan wynika, że przygotowując nauczycieli do pracy w klasach włączających nie wystarczy przekazywać wiedzę o niepełnosprawności, ale należy przede wszystkim skupić się na potencjale uczniów z niepełnosprawnością i nauczać efektywnych sposobów ich kształcenia.

Innym ogólnym komponentem kompetencji zawodowych nauczycieli (obok postaw wobec edukacji włączającej) jest ich poczucie samoskuteczności w pracy z heterogenicznymi grupami uczniów - osobiste przekonanie, że są w stanie podołać zadaniom w klasie, do której uczęszczają uczniowie bez niepełnosprawności i z niepełnosprawnością (Sharma, Loreman, Forlin 2011; Malinen, Savolainen, Xu 2012). Z reguły uznaje się, że dotyczy ono subiektywnej opinii nauczycieli o ich możliwościach skutecznego działania w trzech kluczowych sferach: efektywnego kształcenia wszystkich uczniów, radzenia sobie z trudnymi zachowaniami podopiecznych oraz współpracy ze specjalistami i z rodzicami (Sharma, Loreman, Forlin 2011). Istnieją dowody empiryczne, że program kształcenia nauczycieli może mieć wpływ na ich poczucie samoskuteczności w zakresie edukacji włączającej. Badanie studentów kierunków nauczycielskich z czterech uczelni w różnych krajach (Australia, Hongkong, Kanada i Indonezja) wykazało, że umieszczenie kursów z zakresu pedagogiki specjalnej w programie studiów wpływa na wzrost poczucia saskuteczności (Loreman, Sharma, Forlin 2013). Także w omawianych wcześniej badaniach (Lifshitz, Glaubman, Issawi 2004) wykazano, że cecha ta może być kształtowana za pomocą odpowiednich szkoleń. 
Ostatni obszar kompetencji nauczycieli, istotny z punktu widzenia edukacji włączającej, to różnego rodzaju specyficzne umiejętności metodyczne i organizacyjne. Należy przede wszystkim podkreślić, że pedagodzy dobrze przygotowani do prowadzenia zajęć są wyposażeni w kompetencje metodyczne potrzebne do skutecznego nauczania w klasach włączających. Istnieją dowody na to, że metody i strategie dydaktyczne skuteczne w nauczaniu uczniów bez niepełnosprawności sprawdzają się również podczas kształcenia uczniów z niepełnosprawnością (Mitchell 2016; Vaughn, Gersten, Chard 2000). Do takich strategii zalicza się przede wszystkim: udzielanie uczniom częstych, wyczerpujących informacji zwrotnych na temat ich postępów i wzmacnianie ich motywacji do uczenia się, stosowanie metod opartych na współpracy, klarowne, dobrze ustrukturyzowane prezentowanie materiału z wykorzystaniem zasad uniwersalnego projektowania zajęć, umiejętne stosowanie technologii informacyjnych do indywidualizowania nauczania i upoglądowienia materiału, a także efektywne zagospodarowanie czasu lekcji.

Oprócz tego istnieje grupa umiejętności specyficznych. Zalicza się do nich opracowywanie Indywidualnych Planów Kształcenia (w Polsce znanych jako Indywidualne Programy Edukacyjno-Terapeutyczne) oraz monitorowanie ich realizacji i modyfikowanie zależnie od potrzeb, rozwijanie kompetencji społecznych uczniów i kształtowanie prawidłowych relacji w heterogenicznych grupach rówieśniczych oraz zdolność do współpracy w wielospecjalistycznych zespołach, która jest związana ze znajomością odpowiedniej terminologii i sposobów myślenia osób o różnym wykształceniu (Blacker, Boakes 2010; Europejska Agencja 2012). 